\title{
FACTORS INFLUENCING TEACHERS' INCLINATION TO USE IMPROVISED RESOURCES IN LIFE SCIENCES CLASSROOMS
}

\author{
Mahlatse Ramothwala, \& Sam Ramaila \\ Department of Science and Technology Education, University of Johannesburg (South Africa)
}

\begin{abstract}
A substantial number of schools in South Africa are still under-resourced and this predicament poses fundamental challenges to the provision of quality education for all. The use of improvised low-cost resources as an integral part of pedagogic innovation can be adopted as a viable and sustainable alternative to harness affordable resources to foster meaningful science teaching and learning. In view of this crucial imperative, this study primarily focused on the use of improvised low-cost resources in Life Sciences classrooms at selected South African township schools. The study adopted a case study design located within the interpretive research paradigm. Data was collected through semi-structured interviews and lesson observations involving ten purposively selected Life Sciences teachers. The study revealed that key factors influencing teachers' inclination to use improvised resources include general lack of essential laboratory resources, the need to demystify complex scientific concepts to ensure meaningful conceptual understanding by using available affordable alternative resources as well as harnessing the affordances of improvisation as an innovative means to stimulate meaningful teaching and learning. While the affordances associated with the use of improvised resources have been duly acknowledged by the participants in this study, fundamental challenges and limitations afflicting the deployment of improvised resources remain. In particular, Life Sciences teachers involved in the study postulated that the use of improvised resources may serve to perpetuate misconceptions and that lack of requisite creativity can adversely affect the crafting of improvised resources necessary for teaching difficult topics. Implications for pedagogic innovation are discussed.
\end{abstract}

Keywords: Improvisation, low-cost resources, pedagogic innovation.

\section{Introduction}

The availability of essential resources is a key requirement for provision of quality education for all. However, the South African basic education system is largely characterised by inequitable access to resources (Sedibe, 2011). In addition, a substantial number of schools in South Africa are still under-resourced. This predicament calls for pedagogic innovation on the part of teachers as key agents of educational change to harness the affordances of improvised resources to demystify abstract scientific concepts. Obawuike (2018) explains improvisation in science education as the process of creating alternative materials of teaching by replicating standard materials to function similarly as the original ones using locally sourced materials. Improvisation is essentially the act of construction of instructional materials from locally available materials that can adequately replace or function in place of the original material which otherwise may be very expensive or in short supply or unavailable (Samba \& Eriba, 2011). Given the need to harnes the sffordances of improvised resources within the broader South African educational context, this study primarily explored factors influencing teachers' inclination to use improvised resources in Life Sciences classrooms.

\section{Research design and methodology}

The study adopted a case study design located within the interpretive research paradigm. Data was collected through semi-structured interviews and lesson observations involving ten purposively selected Life Sciences teachers in South African township schools. These township schools were largely under-resourced. 


\section{Findings}

Table 1 below provides teachers' responses on factors influencing their inclination to use improvised resources in Life Sciences classrooms. A likert scale was used to categorise the distribution of teachers' responses: Strongly Agree $=\mathrm{SA}$, Agree $=\mathrm{A}$, Neutral $=\mathrm{N}$, Disagree $=$ DA and Strongly Disagree $=\mathrm{SD}$.

Table 1. Factors influencing teachers' inclination to use improvised resources in Life Sciences classrooms.

\begin{tabular}{|l|c|c|c|c|c|}
\hline $\begin{array}{l}\text { Factors influencing teachers' inclination to use } \\
\text { improvised resources in Life Sciences classrooms }\end{array}$ & \multicolumn{5}{|c|}{$\begin{array}{l}\text { Distribution of teachers' } \\
\text { responses }\end{array}$} \\
\cline { 2 - 6 } & SA & $\mathbf{A}$ & $\mathbf{N}$ & DA & SD \\
\hline Lack of teaching aids in schools & & & & \\
\hline Lack of well-equipped science laboratories & $60 \%$ & $20 \%$ & $20 \%$ & $0 \%$ & $0 \%$ \\
\hline $\begin{array}{l}\text { Improvised resources make it easy for learners to } \\
\text { understand complex scientific phenomena and to relate } \\
\text { it to everyday life. }\end{array}$ & $70 \%$ & $20 \%$ & $10 \%$ & $0 \%$ & $0 \%$ \\
\hline $\begin{array}{l}\text { Improvised resources are cheap, easily accessible and } \\
\text { manufactured }\end{array}$ & $80 \%$ & $20 \%$ & $0 \%$ & $0 \%$ & $0 \%$ \\
\hline $\begin{array}{l}\text { Improvised resources can adequately replace and } \\
\text { function in place of original materials }\end{array}$ & $20 \%$ & $20 \%$ & $0 \%$ & $30 \%$ & $30 \%$ \\
\hline
\end{tabular}

As reflected in Table 1 above, the vast majority of the teachers indicated that general lack of essential resources in township schools is one of the key factors influencing their inclination to use improvised resources in Life Science classrooms. In addition, the teachers expressed positive sentiments about the affordances of improvised resources. However, the teachers were ambivalent about the use of improvised resources as a replacement of original materials. This implies that improvised resources can essentially be used to complement original materials. As illustrated in Figure 1 below, some of the pedagogical affordances of improvised resources in Life Sciences teaching and learning include stimulation of learners' interest in various topics, enhancement of meaningful conceptual understanding of abstract scientific concepts, accessibility of improvised resources to stimulate pedagogic innovation and provision of context-specific science instruction.

Figure 1. Teachers' perceptions about the pedagogical affordances of improvised resources in Life Sciences teaching and learning.

\section{The benefits of using Improvised teaching resources in Life Sciences teaching and learning}
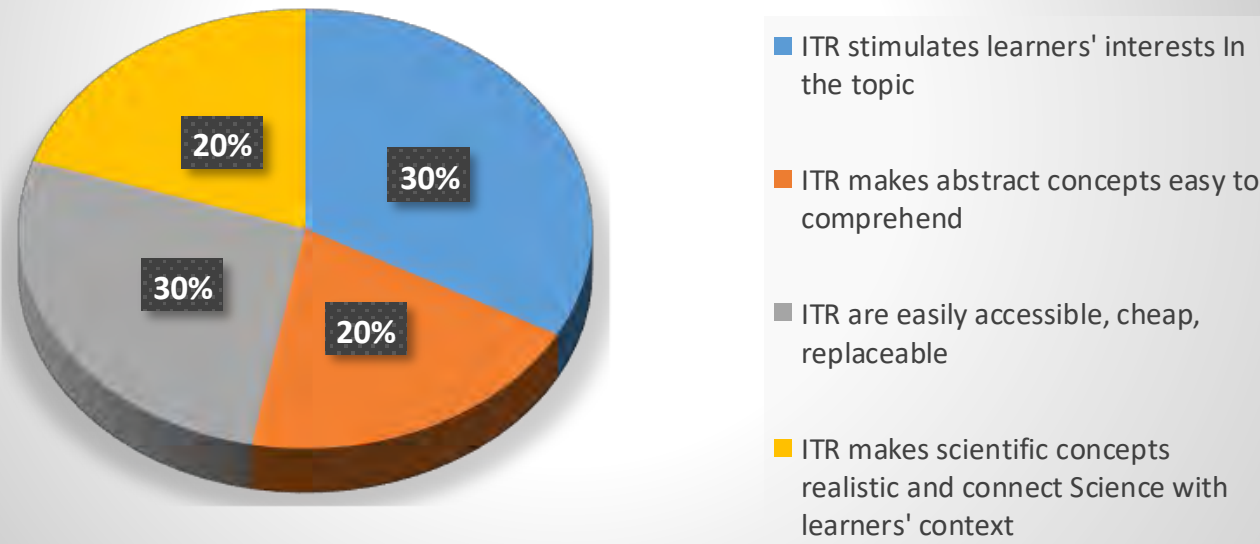
The teachers demonstrated fundamental appreciation of the pedagogical affordances of improvised resources as reflected in the following excerpt.

When conducting experiments with grade 10 learners, I ask them to come along with transparent, small $(300-500 \mathrm{ml})$ plastic bottles to use as beakers. When teaching blood circulatory system, I use charts with flow diagrams to illustrate oxygenated blood and deoxygenated blood.

The teachers bemoaned general lack of resources as a key impediment to the enhancement of meaningful teaching and learning as the following excerpt demonstrates.

In this school we do not have Labs, nor a science budget. I had to use a chart with a kidney drawing to illustrate the internal structure of the kidney.

\section{Discussion}

The key findings of study revealed that key factors influencing teachers' inclination to use improvised resources include general lack of essential laboratory resources, the need to demystify complex scientific concepts to enhance meaningful conceptual understanding by using available affordable alternative resources as well as harnessing the pedagogical affordances of improvisation as an innovative means to stimulate meaningful teaching and learning. While the pedagogical affordances associated with the use of improvised resources in Life Sciences teaching and learning have been duly acknowledged by the teachers, fundamental challenges and limitations afflicting the deployment of improvised resources remain. In particular, the teachers postulated that the use of improvised resources may serve to perpetuate misconceptions if they are not properly integrated and that lack of requisite creativity can adversely affect the design of improvised resources necessary for teaching difficult topics. Olagunju and Abiona (2008) argue that the inadequacy of teaching materials or resources, laboratory equipment and laboratory space has been a key area of concern for teachers. Obawuike (2018) posits that that the driving-force for adopting improvisation-based teaching approaches is the lack of standard science equipment in schools. In navigating this complex predicament, teachers resort to utilization of improvised resources to reduce and save costs (Obawuike, 2018). The provision of quality science education within the South African context is largely hampered by lack of essential resources. In support of this notion, Parker (2018) postulates that effective teaching and learning of sciences requires the incorporation of instructional materials to foster pedagogic innovation rather than undue reliance on traditional instructional methods.

The teachers demonstrated fundamental appreciation of the pedagogical affordances of improvised resources in Life Sciences teaching and learning. This finding is consistent with a research study conducted by Mboto, Ndem and Stephen (2011) which established that the use of improvised instructional materials makes learners to understand better, perform well, enhances teaching and learning of science as they make the learning process interesting and enjoyable. A study conducted by Obawuike (2018) demonstrated that science learners taught using improvised instructional materials performed better than those taught using traditional approaches. Parker (2018) concurs by affirming that the use of improvised materials for experiments enables learners to take part in hands-on construction of apparatus. Parker (2018) further asserts that the use of improvised instructional resources provides meaningful platforms to demystify abstract scientific concepts for learners.

\section{Conclusion}

Improvised instructional resources can be used to circumvent general lack of resources in South African township schools. There is a crucial need to harness the pedagogical affordances of improvised instructional resources with a view to foster meaningful science teaching and learning through pedagogical innovation. 


\section{References}

Mboto, F. A., Ndem, N. U. \& Stephen, U. (2011). Effects of Improvised materials on Student's Achievement and Retention of the Concept of Radioactivity. African Research Review - An International Multi-Disciplinary Journal, Ethiopia, 5(1), 342-348.

Olagunju, A.M, \& Abiona, O.F. (2008). Production and utilization of resources in biology education. A case study of South West Nigerian secondary schools. International Journal of African \& African American Studies, VII (2), 51-56.

Parker, J., Osei-Himah, V. \& Asare, I. (2018). The effects of improvised materials on the study of science in basic schools in Aowin Municipality-Ghana. Research on Humanities and Social Sciences. ISSN 2224-5766.

Samba, R. M. O, \& Eriba, J. O. (2011). Laboratory Techniques and the Art of Improvisation. Makurdi: His Masters Servant Media Apostolate Publications.

Sedibe, M. (2011) Inequality of access to resources in previously disadvantaged South African high schools. Journal of Social Sciences, 28(2), 129-135.

Ubawuike, A.B. (2018). Effects of teachers' use of improvised instructional materials on students' academic performance in Physics. International Journal of Social Sciences and Management Research, 4(7), 2545-5303. 